\title{
Inflation Metaphor in the TIME Magazine Corpus
}

\author{
Chunyu $\mathrm{Hu}^{1} \&$ Huijie Liu ${ }^{1}$ \\ ${ }^{1}$ School of English for International Business, Guangdong University of Foreign Studies, China \\ Correspondence: Chunyu Hu, Professor of School of English for International Business, Guangdong University \\ of Foreign Studies, Guangzhou 510420, China. Tel: 86-20-3631-7183. E-mail: gwhcy@gdufs.edu.cn
}

Received: November 14, 2015 Accepted: January 10, 2016 Online Published: January 13, 2016

doi:10.5539/elt.v9n2p124

URL: http://dx.doi.org/10.5539/elt.v9n2p124

\begin{abstract}
A historical perspective on economy metaphor can shed new lights on economic thoughts. Based on the TIME Magazine Corpus (TMC), this paper investigates inflation metaphor over 83 years and compares findings against the economic data over the relatively corresponding period. The results show how inflation, an abstract concept and a normal economic phenomenon, is typically understood and explained in a variety of metaphoric expressions, how different types of metaphor structure and reframe our thinking about inflation, and why the usage of inflation metaphor varied over time. This study highlights the importance of historical perspective and the values of diachronic corpus in researching economy metaphor.
\end{abstract}

Keywords: corpus, collocation, inflation metaphor, TIME Magazine, historical perspective

\section{Introduction}

The importance of inflation in modern economy cannot be overestimated. The impact of inflation was eloquently expressed by J. M. Keynes (cited in Samuelson \& Nordhaus, 2010): "As inflation proceeds and the real value of the currency fluctuates wildly from month to month, all permanent relations between debtors and creditors, which form the ultimate foundation of capitalism, become so utterly disordered as to be almost meaningless; and the process of wealth-getting degenerates into a game and a lottery." Whereas economists can gauge inflation by calculating CPI (Consumer Price Index) or GDP Deflator, inflation, as a rather abstract concept, imposes a great challenge for the public. It thus comes no surprise that most people tend to use metaphors to grasp the difficult-to-understand economic phenomenon.

In their classical study, Lakoff and Johnson (1980) claims that the metaphor INFLATION IS AN ENTITY can be instantiated by Inflation is lowering our standard of living, we need to combat inflation, and many other metaphorical expressions. They argued that viewing inflation as an entity enables its quantification, the identification of its particular aspects, seeing it as a cause, and even believing that we understand it, and this metaphor is "necessary for even attempting to deal rationally with our experiences" (Lakoff \& Johnson, 1980: 26). Attributing animate features to the inanimate concept inflation "not only gives us a very specific way of thinking about inflation but also a way of acting toward it" (Lakoff \& Johnson, 1980).

Based on a small corpus, Silaski and Durovic (2010) identifies six types of sub-metaphors of INFLATION IS A FEROCIOUS ANIMAL, in which the most salient properties associated with wild animals (the ways they look, eat, behave, sound, attack, as well as the ways they are tamed, controlled, caught or killed) are mapped onto the target domain, INFLATION.

Taking a diachronic perspective, Berber Sardinha (2012) has traced 50 years of metaphors that have been used to refer to the Brazilian economy (particularly to inflation) and has found that the last half century of Brazilian economics has been dominated 'by the struggle to defeat inflation', and that the economic plans of that struggle were systematically conceptualized and linguistically expressed by a series of framing metaphors. The essential role of the inflation metaphors allows the author to conclude that it would be "hard to imagine such large-scale initiatives becoming popular or even plausible without major framing metaphors accompanying them" (Berber Sardinha, 2012).

Using a 450-million-word Corpus of Contemporary American English (COCA), Hu and Chen (2015) finds that there exist a considerable number of metaphorical collocates of inflation, which can be grouped into separate yet closely related categories: INFLATION IS FIRE, INFLATION IS DISEASE, INFLATION IS A FEROCIOUS ANIMAL, INFLATION IS AN ENEMY, and INFLATION IS A RACER. Their study also demonstrates how 
these metaphors function in specific contexts, and how they structure and reframe people's thinking about inflation and other related economic concepts.

It is clear from the literature that the diachronic study of inflation metaphor is rare and inadequate. The importance of historical perspective in the study of economy metaphor, however, is of vital importance, as strongly argued by Moulton:

an adequate analysis of any given economic metaphor should pay proper attention to its historical situatedness. ... A historical perspective thereby helps us to see that the metaphors underlying economic reasoning should be seen as flexible and dynamic processes, rather than as fixed and static systems. Put differently, by shifting away from the synchronic stance that shapes most contemporary perspectives on metaphor, one avoids being misled into thinking that a particular set of mappings constitute a permanent state in a static system, when it is really just a temporary station in a dynamic process. (Moulton, 2012)

Building on previous studies, this paper aims to research inflation metaphor by examining a number of diachronic corpora and then discuss results from a socio-cultural perspective. In order to lay a sound theoretical and methodological foundation, we will first review the relevant literature regarding the Conceptual Metaphor Theory (CMT), the distinction between conceptual and linguistic metaphors, and metaphor identity procedure.

\section{Related Work}

\subsection{Conceptual Metaphor Theory}

Metaphor has aroused great interest since Aristotelian times. A widely shared view is that metaphor is a figure of speech, a linguistic phenomenon based on a resemblance between the two entities that are compared and identified, used for some artistic and rhetorical purpose. As a device of the poetic imagination and the rhetorical flourish, metaphor is not an inevitable part of everyday human thought and reasoning. One must have a special talent to be able to use metaphor, and only great poets or eloquent speakers can be its masters.

This entrenched view has been challenged by Lakoff and Johnson (1980) in a coherent and systematic way. They have argued that (1) metaphor is a property of concepts instead of mere words; (2) the function of metaphor is to better understand certain concepts, and not just some artistic or aesthetic purpose; (3) metaphor is often not based on similarity; (4) metaphor is used effortlessly in everyday life by ordinary people, not just by special talented people; and (5) metaphor, far from being a superfluous though pleasing linguistic ornament, is an inevitable process of human thought and reasoning. The new view of metaphor is labeled as Conceptual Metaphor Theory (CMT).

An important notion in CMT is the conceptual domain which can be viewed as any coherent organization of experience. Metaphor is defined as conceptualizing one domain of experience in terms of another, or more simply TARGET DOMAIN IS SOURCE DOMAIN (Lakoff, 1993). The source domain is typically more physical, more directly experienced, and better known than the target domain which is typically more abstract, less directly experienced, and less known. For instance, we have coherently organized knowledge about journey that we rely on in understanding life, leading to a common conceptual metaphor LIFE IS A JOURNEY.

\subsection{Metaphorical Expressions}

It is important to distinguish conceptual metaphor from metaphorical linguistic expressions. It is vital in any discussion of metaphor to distinguish between the metaphorical concept and the language that expresses that concept (Lakoff \& Turner, 1989). Conceptual metaphor refers to a mapping from the source domain to the target domain, whereas metaphorical linguistic expressions refer to the linguistic words or phrases to illustrate conceptual metaphors.

An illustrating example is the conceptual metaphor LOVE IS A JOURNEY in which aspects of love are metaphorically expressed in the domain of journey. Typical of metaphorical linguistic expressions include Look how far we've come, We're at a crossroads, We'll just have to go our separate ways, We can't turn back now, and the like, and the like (Kövecses, 2002). It has to be pointed out that mapping from the source domain to the target domain are firmly structured, and normally unconscious to people except for the purposeful analysis when people need to bring the mappings into awareness (Kövecses, 2002).

\subsection{Metaphor Identification Procedure}

Metaphor identification has to meet certain generally accepted standards of methodological quality. A group of researchers, called the Pragglejaz Group, designed metaphor identification procedure (MIP). Designed by ten experienced metaphor researchers over six years, MIP is a tool for linguistic metaphor identification in natural discourse. MIPVU is a refined and extended version of MIP, of which VU stands for Vrije Universiteit. MIPVU 
leads to results that are methodologically reliable and empirically revealing (Steen et al., 2010).

The theoretical conceptualization of metaphor as a cross-domain mapping leads to a view of metaphor in language as based on indirectness plus similarity. The basis of the identification of metaphor has thus been regarded as a matter of finding indirect meaning in lexical units by a number of cognitive linguists (Lakoff, 1993; Gibbs, 1994). It suggests that metaphorical meaning is indirect meaning which is potentially motivated by similarity or cross-domain mapping. Linguistic metaphor identification involves looking at some contrast and comparison between contextual meanings and basic meanings.

Steen et al. (2010) argues that although indirectness is a good starting point for finding metaphor in language, it is both too broad and too narrow, however. Based on years' hard work, they have provided a comprehensive procedure of metaphor identification: 1) identify the contextual meaning of the lexical unit; 2) check if there is a more basic meaning of the lexical unit. If there is, establish its identity; 3) determine whether the more basic meaning of the lexical unit is sufficiently distinct from the contextual meaning; 4) examine whether the contextual meaning of the lexical unit can be related to the more basic meaning by some form of similarity (Steen et al., 2010).

\section{Method}

\subsection{Corpora}

The corpus used in the study is the 100-million-word TIME Magazine Corpus (TMC) created by Mark Davies of Brigham Young University. TMC (Davies, 2007) contains all the content from the online archive of TIME magazine from 1923 to 2006, a popular American weekly news journal. The archive dates back to the first edition of TIME, published in March 1923, and contains every weekly edition and all special editions published up until the present day. In excess of 100 million words in size, the corpus contains over 275,000 articles. The corpus is tagged for parts of speech (POS) using the CLAWS tagset, and it is accessible through a free online interface (http://corpus.byu.edu/time/). This allows the user to restrict searches by POS tag and/or by decade. The search output (see Figure 1) provides the user with, among other options, raw frequencies, sub-corpus size and standardized frequencies for each year; concordances with context; a hyperlink to the original article; and a graphical representation of data.

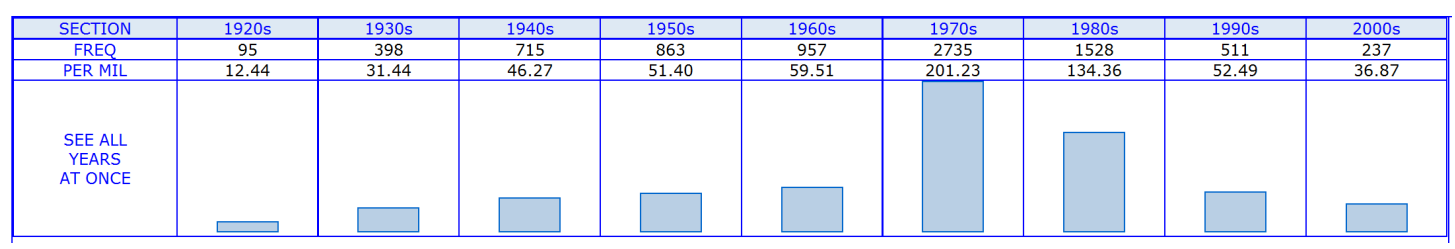

Figure 1. The distribution of inflation in Time Magazine Corpus

\subsection{Corpus Tools}

The corpus tool used in this study is the Brigham Young University (BYU) online interface, which falls into the category of fourth-generation concordancers. The system was developed by Mark Davies, and, to date, it is probably the most powerful, and most widely used, SQL-based corpus analysis tool (McEnery \& Hardie, 2012). The BYU online interface allows users to search for exact words or phrases, wildcards, lemmas, part of speech, or any combinations of these. One can also search for collocates within a ten-word window (e.g. all nouns, all adjectives, or all verbs near a search word).

\subsection{Analysis Procedures}

There are five steps in this study. The first one is to generate the frequency of inflation in TIME Magazine Corpus from 1923 to 2006, as shown in Table 1. The second one is to generate collocates of inflation in TMC by employing the BYU system. The BYU online interface provides MI (Mutual Information) measure to calculate the strength of a collocation. Generally, MI-score measures the amount of non-randomness present when two words co-occur. A MI-score of 3 or higher can be taken to be significant (Hunston, 2002) and that is probably why the default value is 3 in the BYU system. The optimal span of calculating collocates is 4:4, as stated in Sinclair (1991), "Collocation is the cooccurrence of two or more words within a short space of each other in a text. The usual measure of proximity is a maximum of four words intervening". When setting the 4:4 span, MI-score 3, the system generates 1600 lemmas as collocates of inflation. Below are ten most frequent lemmas: 
Table 1. The first 10 most frequent collocates of inflation in TMC

\begin{tabular}{llllll}
\hline Collocates & Frequency & MI Score & Collocates & Frequency & MI Score \\
\hline rate & 712 & 5.42 & economy & 712 & 4.04 \\
price & 267 & 3.27 & rise & 267 & 3.13 \\
unemployment & 254 & 6.37 & interest & 254 & 3.25 \\
fight & 222 & 3.42 & low & 222 & 3.26 \\
control & 183 & 3.21 & recession & 183 & 5.86 \\
\hline
\end{tabular}

The third step is to search the collocates of inflation in TMC in order to find out metaphor keywords, each of which will then be closely examined by perusing its concordance lines one by one before determining whether it is used metaphorically or literally. In general, our research follows the practice of metaphor identification procedure suggested by Steen et al. (2010). The importance of reading concordance lines can be highlighted in the examples below where the word resurgence in (1) is a real collocate of inflation whereas in (2) it is the collocate of values instead of inflation.

(1) One of the baleful aspects of the industrial world's quickening economic upturn is the possibility of a resurgence of global inflation (TMC 1976/01/19)

(2) Barring bad luck and bad management, the last 18 years of the century should see higher productivity, lower inflation and a resurgence of traditional values (TMC 1982/08/16).

The forth step is to classify metaphorical collocates into different categories. Given the overlapping features among different types of metaphors, it may as well cause problems to the task of assigning certain metaphorical expressions to metaphorical concepts. Henderson (1982) sees metaphor "as a device for exploring specific economic problems and as a basis for extending the domain of economic ideas". He proposes the idea of root metaphors which provide a "sustained basis for the organization of the discussion of a topic and for the selection of terms that are used to discuss the topic" (Henderson, 1994). Some important root metaphors that permeate the discourse of economics are the organic metaphor, where economic phenomena and entities are similar to living organisms that grow, suffer or flourish, the mechanical metaphor, where the economy is likened to a machine that starts up, slows down or overheats, and the liquid metaphor, where economic phenomena may circulate, flow or float (Henderson, 2000; Charteris-Black, 2000; White, 2003; O'Mara-Shimek et al., 2015).

Based on previous studies, we produced a checklist for the metaphor-related words of inflation. However, some modification of classification was made for some controversial words. The Oxford English Dictionary has been frequently referred to when it was hard to identify the source domain of each word under investigation. For instance, halt was labeled by Crawford Camiciottoli (2007) as mechanical metaphor. The investigation of OED, however, indicates that halt was originally "a temporary stoppage on a march or journey" used as a military phrase. We thus reclassified halt in example (3) as warfare metaphor. The word hedge is defined in the OED as "a row of bushes or low trees (e.g. hawthorn, or privet) planted closely to form a boundary between pieces of land or at the sides of a road: the usual form of fence in England." And this meaning can be further explained as "to buffer or cushion damages from outside as a means of protection or defense". Hence, we classified hedge in example (4) into the plant metaphor, which is a subcategory of organic metaphor. Items as creeping in example (5) and raging in example (6) are classified others under the heading of human being, in fact that they cannot fit into warfare, sports, nor disease, as shown in Table 2.

(3) Crippling controls have been lifted from the backs of the American worker, consumer and businessman, while inflation has been halted, thrift put into federal operations and efficiency brought to Government (TMC 1954/10/11).

(4) Last week in the current issue of his monthly business review, Analyst Ayres undertook to destroy the common faith in common stocks as a hedge against inflation (TMC 1936/04/27).

(5) Serious depressions are no longer the threat they once were, while creeping inflation has become a chronic feature of recent history and a growing threat to the welfare of millions of people.(TMC 1958/01/06)

(6) In addition, the higher prices for oil and natural gas that Ford plans could restore the raging inflation that is only now beginning to relax its debilitating grip on the U.S. (TMC 1975/01/27).

Calculating resonance of source domains is the final step. According to Charteris-Black (2004), resonance is the 
sum of the tokens multiplied by the sum of the types of the metaphors that are from the same source domain. By providing empirical evidence for the resonance of different source domains, the resonance serves as an indication of the extent to which metaphor source domains are found in a particular corpus and therefore is a measure of their productivity.

\section{Results and Analysis}

\subsection{Frequency Change of Inflation in Time Magazine}

The TMC architecture and interface allow users to see the frequency of inflation in each of the nine decades in the corpus from the 1920s to the 2000s. The frequency chart in Figure 1 shows that inflation is increasingly more frequent from 1920s onward and reaches its peak in 1970s, and then declines ever since.

\subsection{Subtypes of Inflation Metaphor}

Table 2 lists the metaphorical collocates of inflation according to root metaphor category along with their frequencies in parentheses.

Table 2. Specific inflation metaphors in the TMC

\begin{tabular}{|c|c|}
\hline Root & Items \\
\hline Fire & $\begin{array}{l}\text { (re)fuel (55), (re)kindle (12), (re)ignite (12), stoke (8), flare (5), scorch (3), bonfire (3), fire (1), } \\
\text { tinder (1), firehouse(1) }\end{array}$ \\
\hline Liquids & $\begin{array}{l}\text { surge }(25) \text {, ravage }(25) \text {, erode (19), resurge (15), ebb (4), upsurge (3), corrode (3), dike (2), } \\
\text { riptide (1), backwash(1), floodgate(1), re-emerge(1), spigot (1) }\end{array}$ \\
\hline Plant & hedge (75), stem (14), bud (1) \\
\hline Animal & $\begin{array}{l}\text { curb }(123) \text {, runaway }(79) \text {, gallop }(51) \text {, soar }(54) \text {, rampant }(29) \text {, roar }(34) \text {, spur }(10) \text {, tame }(16) \text {, } \\
\text { rein }(7) \text {, hover }(6) \text {, rampage }(5) \text {, gnaw (3), bridle (3), giddy (3), ravenous }(1) \text {, bay (1), canter } \\
(1) \text {, hoof }(1)\end{array}$ \\
\hline Disease & $\begin{array}{l}\text { plague (22), virulent (16), outbreak (12), chronic (14), pang (4), dizzy (4), feverish (2), cure-all } \\
(2) \text {, malaise (2), incurable (2), antidote (2), gangrene (1), hamstring (1), exacerbate (1) }\end{array}$ \\
\hline Warfare & $\begin{array}{l}\text { fight (260), threat (60), combat (48), halt ( } 35) \text {, quell (6), destructive (4), bulwark (3), beater } \\
\text { (3), subdue (3), battle (2), defence ( } 1) \text {, defeat (1) }\end{array}$ \\
\hline Sports & (out)pace (51), wrestle (6), abreast (6), outstrip (4) \\
\hline Others & $\begin{array}{l}\text { creep (36), rage (16), infuriate (8), nag (4), bogey (5), scourge (3), cripple(1), crawl(1), } \\
\text { company(1), specter (1), nourish (1), accompany (1), ravish (1) }\end{array}$ \\
\hline Mechanical & $\begin{array}{l}\text { control (176), slow (88), check (96), accelerate (32), brake (20), (sky)rocket (15), slowdown } \\
\text { (7), throttle (4), slacken (2), escalate (2), speed (2), rig (1), whipsawed (1), decelerate (1), } \\
\text { quicken (1) }\end{array}$ \\
\hline Orientational & $\begin{array}{l}\text { rise (121), low (121), spiral (41), subside (9), upward (6), lessen (6), decline (4), debase (4), } \\
\text { sky-high (2), downturn (2), reduce (2), diminish (2), uptick (2), abate (1) }\end{array}$ \\
\hline
\end{tabular}

It is evident that our thinking of inflation is metaphorical by nature. We borrow ideas from the domain of fire, liquids, animal, disease, warfare, sports or orientation that seems familiar to us and project them to the more abstract and elusive domain of inflation so that we can become alert to the danger or potential harmful effect of inflation. Below is a relatively detailed analysis of each subtype of inflation metaphor.

\subsubsection{Inflation Is Fire}

Fire is often used as the source domain for some intangible entity. For instance, ANGER IS FIRE (Lakoff, 1987). In this study, a number of items in the source domain FIRE such as fuel (refuel), kindle (rekindle) or bonfire are mapped onto the target domain INFLATION. Interestingly, when we look at the verbal items, it seems that the mapping from the source domain to the target domain is quite structured: stoke/kindle/ignite $\rightarrow$ fuel $\rightarrow$ dampen $\rightarrow$ rekindle/reignite $\rightarrow$ refuel (fire or inflation). 
(7) The government, which has enforced price cuts on some goods, denies that its ambitious defense budget (up 7.3\% in 1963) has stoked inflation, but more and more Frenchmen are beginning to question the cost and value of De Gaulle's force de dissuasion, as the government now calls its nuclear deterrent (TMC 1983/06/25).

(8) For years policymakers couldn't figure out how to reduce joblessness without flaring inflation (TMC 1997/12/28).

(9) One major reason for all this is a peculiarly vicious circle: to keep up with inflation, workers have been demanding huge wage settlements that fuel further inflation (TMC 1975/06/02).

(10) Consumers, though, would face more expensive heating oil and gasoline, and if prices continue to climb, the increase could rekindle inflation and eventually weaken the world economy (TMC 1986/08/18).

(11) Some economists, on the other hand, fear that the Federal Reserve will reignite inflation, which now is running at less than 5\%, if it does not halt the M1 expansion (TMC 1983/06/25).

\subsubsection{Inflation Is Liquids}

Liquidity or liquids metaphor is not uncommon in economics. According to Resche's (2012) survey, the French economist Quesnay's diagram has inspired other flow diagrams, based on the analogy with the circulation of blood in the human body. Since then, the liquid element has become natural when dealing with money in terms of inflows and outflows of capital, pools of liquidity, or fluctuations. This type of metaphor, however, is less common in our study, with only a few items identified in TMC:

(12) Wall Street does not seem to believe these predictions. Investors fear an upsurge of inflation, or a sharp tightening of money accompanied by rising interest rates, or both (TMC 1976/01/19).

(13) More Americans are unemployed, many others are doing without overtime pay, and inflation has eroded earnings (TMC 1980/06/09).

(14) The Administration gabbled of plans for new controls to fight an inflation that was already ebbing (TMC 1950/01/09).

(15) The Government announced that wholesale prices in July fell $0.4 \%$, their biggest monthly drop in three years, which signaled that inflation is ebbing (TMC 1989/08/21).

\subsubsection{Inflation Is a Plant}

Despite that the plant metaphor is generally infrequent with only three items in this category as illustrated in example (16) to (18), the item hedge is frequently employed.

(16) To hedge against shortages or inflation, many citizens withdrew their savings to purchase such nonperishables as bicycles and textiles (TMC 1984/12/03).

(17) In the same way last March, Goulart persuaded automakers to freeze prices for three months to help stem inflation (TMC 1963/06/07).

(18) By most accounts, the Fed is attempting to nip inflation before it buds, a policy some economists believe could be dangerous (TMC 1988/12/12).

\subsubsection{Inflation Is an Animal}

The INFLATION IS AN ANIMAL metaphor reveals a very complex cognitive structure. Evidence from TMC indicates that the most salient properties of wild animals as a source domain are mapped onto the abstract and complex target domain inflation, producing various conceptual mappings, which refer to the ways that wild animals move, look, sound, eat/are fed, attack and are controlled.

(19) With other U.S. experts, he would refurbish Guatemalan economy, try to rein in the country's galloping inflation (TMC 1945/08/13).

(20) The Administration insists that the U.S.'s present $13 \%$ inflation rate can be tamed by gently slowing the economy. (TMC 1979/12/02).

(21) Meanwhile, foreign currency reserves have been exhausted, inflation soared at a rate of $163 \%$ last year and this year's trade deficit is expected to surpass $\$ 500$ million (TMC 1973/03/19).

(22) As part of its struggle against the nation's roaring inflation, the Ford Administration has announced plans for a sweeping new assault against anticompetitive practices, including price-fixing conspiracies and agreements between companies not to sell in each other's prime market areas (TMC 1973/03/19). 
(23) The U.S. economy is basically strong; its sluggishness this year has been induced by governmental tax, spending and monetary policies aimed at curbing inflation (TMC 1970/12/14).

This study confirms Charteris-Black's (2004) claim that ferocious animals "serve as prototypes for threats and dangers to mankind" and in turn are "typically employed to construct negative evaluations". A seemingly different yet similar source domain is warfare in which inflation is regarded as an enemy.

\subsubsection{Inflation Is an Enemy}

Warfare metaphors play a central part in human life. In view of the harmful effects of inflation, it is not surprising to find a large number of evidences pointing to the more concrete metaphor INFLATION IS AN ENEMY, which is in line with the metaphoric theme of fighting and warfare.

(24) The nation's fight against inflation, begun with President Roosevelt's seven-point program last spring, had turned into a retreat, might soon be a rout (TMC 1942/02/13).

(25) Administration inflation fighters worry most that while wages are rising, productivity in the private nonfarm sector of the economy is declining. (TMC 1974/08/12)

(26) Not only would such a transfer help combat inflation by sopping up credit, it would also make the Treasury's debt management job much simpler by cutting down on refinancing operations (TMC 1957/03/08).

(27) Indeed, a sustained rise in productivity is essential if the U.S. is ever to quell inflation while expanding its economy fast enough to meet its needs for more job opportunities and improved housing, education and medical services (TMC 1974/06/03).

(28) Now he cries for economy, for bulwarks against inflation; he sees ahead a bankrupt country (TMC 1941/08/04).

\subsubsection{Inflation Is a Racer/ Wrestler}

The sports metaphor is much less productive compared with warfare metaphor and disease metaphor under the heading of human being. The typical image aroused is INFLATION IS A RACER in which the rivals of inflation may fall behind pace of (example 29), keep pace with (example 30) or outpace (example 31). Another image aroused in the sports metaphor is INFLATION IS A WRESTLER in which one has to wrestle with, as shown in example (32).

(29) It is a split-level surge in which mass layoffs are continuing side by side with new hiring and heavy overtime; high-income people are making more money, while many others are working at worse jobs for lower wages than a few years ago and still others have seen pay raises, if any, fall behind even today's slow (2.5\%) pace of inflation (TMC 1994/04/25).

(30) An annual pay raise is seldom enough to keep pace with the inflation of living costs and taxes (TMC 1971/08/26).

(31) Despite a slight pullback in the rate of growth, premiums over the past year jumped $11.2 \%$, outpacing inflation and growth in wages by about five times (TMC 2004/09/20).

(32) Europe is wrestling with persistent inflation, and the U.S. is fighting a pernicious international payments imbalance and gold outflow (TMC 1964/04/29).

\subsubsection{Inflation Is Disease}

The disease metaphor is frequently employed in the discourse of economics. "Like diseases, inflations exhibit different levels of severity. It is useful to classify them into three categories: low inflation, galloping inflation, and hyperinflation." (Samuelson \& Nordhaus, 2010). The type of metaphor motivates metaphorical expressions relating to the breakout, diagnosis, and treatment of the economic ailment. Disease can be not that serious, as exemplified in the adjective benign, or be as rampant and virulent as a plague.

(33) The economy, meanwhile, is plagued by chronic inflation (current annual rate: 13\%), has entered a recession and is suffering from a severe energy shortage (TMC 1979/10/30).

(34) The danger is that an overly stimulative policy could cause a new outbreak of virulent inflation (TMC 1986/11/17).

(35) Inflation is an international malaise (see WORLD BUSINESS) and symptoms of it are appearing all over the U.S. Last month wholesale prices climbed at an alarming annual rate of 6\% (TMC 1966/03/04).

(36) Feverish inflation, previously a rare malady limited primarily to wartime, has become chronic (TMC $1980 / 04 / 21)$ 
(37) At home, the blessings of prosperity now threaten to turn into the pangs of inflation (TMC 1969/06/06).

\subsubsection{Inflation Is a Machine}

Apart from entities or phenomena related to organisms and nature, inflation can also be metaphorically described as a machine, and for the most part, a vehicle. There exist various states of motion of a machine: it can slow down, speed up or accelerate. When machine cannot operate smoothly by itself since it may malfunction, measures should be taken to control it or put a brake on it.

(38) Hoping to further Brazil's development and the family fortune simultaneously, they plan to build two new plants to make paper and tile as soon as Brazil's runaway inflation slows down a bit (TMC 1963/06/28).

(39) Then come the threats of a breakdown of world trade -caused partly by protectionism, partly by uncertainty about what exchange rates will be the next day or even the next hour-followed by a speedup in global inflation and, finally, international recession (TMC 1978/03/20).

(40) During the Carter Administration, inflation accelerated sharply when unemployment dipped below 6\%. (TMC 1988/01/23).

(41) On the economic front, Congress would be asked to take steps to control inflation (TMC 1948/11/15).

(42) They believe that a return to the rigid fiscal discipline of the gold standard would act as a brake on inflation by preventing governments from overspending, head off world recessions by doing away with the excesses that lead to them (TMC 1959/10/12).

\subsubsection{The Orientational Metaphor}

The orientational metaphor is a metaphor that involves spatial relationships, which turns out to be quite productive in this study. Closely related to upward orientation is other metaphorical collocates such as soar and surge which also have negative evaluation.

(43) George Bush promised during the campaign that he would fight to keep the defense budget $2 \%$ above the rise of inflation, but he is unlikely to get that much without a tax increase (TMC 1988/12/05).

(44) But Administration economists are betting that an economic slowdown will help lower the inflation rate to something like $4 \%$ or $5 \%$ in the second half of 1974 (TMC 1974/02/18).

(45) Inflation is drifting upward, while economic activity seems stuck in a quagmire of intense foreign competition and excessive debt (TMC 1990/02/12).

(46) Instead of the vicious cycle of ever higher costs, the economy has now entered a virtuous cycle of declining inflation (TMC 1982/10/03).

(47) The result is a spiraling real estate inflation that has lifted Japan's urban-land price index $670 \%$ since 1955 , has made land in Japan the most expensive in the world (TMC 1965/01/08).

\subsubsection{The Combination of Subtype Metaphors}

Different source domains may combine to make the abstract concept inflation more vivid, as demonstrated in example (48)-(51):

(48) Israel fights a losing battle against creeping inflation, badly needs capital for industrial development, a situation that is not improved by high military expenditures (TMC 1951/08/21).

(49) Like more worldly organizations, the Vatican is plagued by galloping inflation and an increasingly high overhead (TMC 1979/11/19).

(50) The new government of President Miguel de la Madrid Hurtado, which was inaugurated in December, has begun an austerity program aimed at slashing Mexico's huge budget deficit, halting unnecessary government spending programs and slowing its virulent, 116\% inflation (TMC 1983/06/13).

(51) Many experts believe that deficits have been pushed perilously close to their manageable limit, and that if they continue, chronic inflation is certain to flare up (TMC 1972/01/10).

\subsection{Resonance of Source Domains}

The literature has underlined frequent references to the economy as a machine or a human being. The recurring networks of organic or mechanistic metaphors in connection with theory-constitutive metaphors in economics have been investigated from a historical perspective (cf. Radman, 1997; Mouton, 2012; Resche, 2012). This study confirms previous studies in that organic and mechanical are still dominant metaphors. It also demonstrates that other source domains like natural phenomenon and orientation are also frequently mapped 
onto the target domain INFLATION.

Table 3. Resonance of each subtype of inflation metaphor

\begin{tabular}{|c|c|c|c|c|c|}
\hline \multicolumn{3}{|c|}{ Group of Metaphor } & \multirow{2}{*}{$\begin{array}{l}\text { Type } \\
10\end{array}$} & \multirow{2}{*}{$\begin{array}{l}\text { Token } \\
100\end{array}$} & \multirow{2}{*}{$\begin{array}{l}\text { Resonance } \\
1000\end{array}$} \\
\hline \multirow{3}{*}{$\begin{array}{l}\text { Natural } \\
\text { Phenomenon }\end{array}$} & \multicolumn{2}{|l|}{ Fire } & & & \\
\hline & \multicolumn{2}{|l|}{ Liquid } & 13 & 101 & 1313 \\
\hline & \multicolumn{2}{|l|}{ Total } & 23 & 201 & 4623 \\
\hline \multirow{8}{*}{ Organic } & \multicolumn{2}{|l|}{ Plant } & 3 & 90 & 270 \\
\hline & \multicolumn{2}{|l|}{ Animal } & 17 & 422 & 7174 \\
\hline & & Warfare & 12 & 426 & 5112 \\
\hline & Human & Sports & 4 & 67 & 268 \\
\hline & \multirow[t]{3}{*}{ Being } & Disease & 15 & 88 & 1320 \\
\hline & & Others & 13 & 72 & 936 \\
\hline & & Total & 44 & 653 & 28732 \\
\hline & \multicolumn{2}{|l|}{ Total } & 64 & 1165 & 74560 \\
\hline \multicolumn{3}{|l|}{ Mechanical } & 15 & 448 & 6720 \\
\hline \multicolumn{3}{|l|}{ Orientational } & 14 & 323 & 4522 \\
\hline
\end{tabular}

\section{Discussion: Linguistic Data vs. Economic Data}

Having presented the frequency change of inflation over 83 years, the metaphorical expressions of inflation over TMC and the relevant resonance of each source domain, it would be more fruitful to discuss the observed findings in the light of the social-cultural context that inflation metaphor has been used over almost 100 hundred years. For that purpose we will compare linguistic data against economic data from a well-known economic textbook Economics (Samuelson \& Nordhaus, 2010). Figure 2 shows inflation rate in the United States over sixty years. Clearly inflation was variable, and it reached unacceptable high rates in the early 1980s. However, it has moved in a narrow range in recent years. The general trend based on economic data as in Figure 2 is similar to that attested from corpus data as shown in Figure 1.

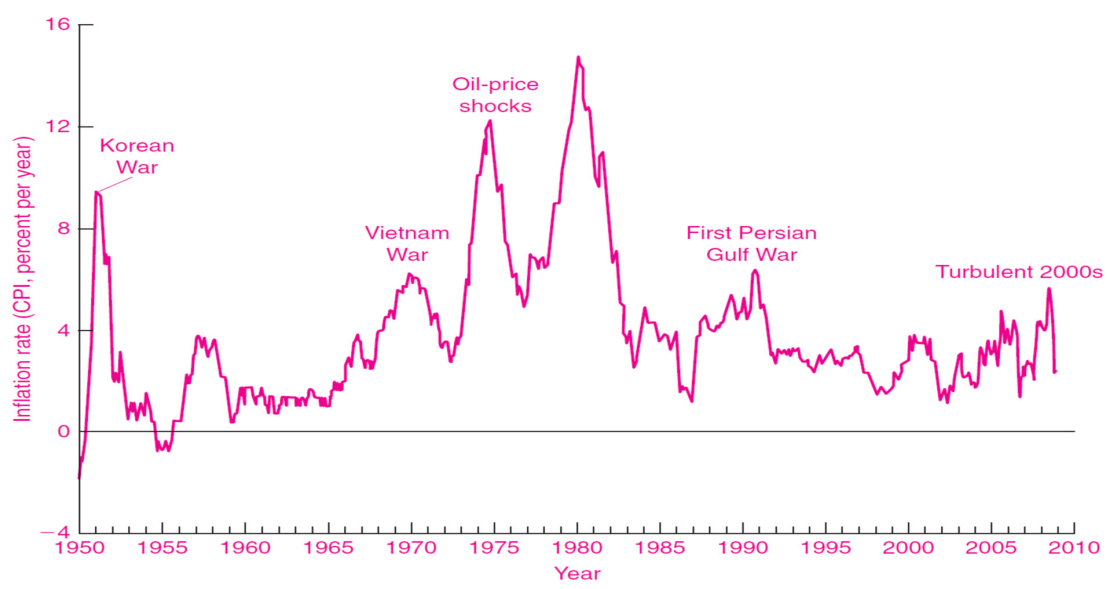

Figure 2. Inflation rate over 60 years (Samuelson \& Nordhaus, 2010)

The major exception is the period during the early 1950s. Nevertheless, a detailed investigation of TMC suggests that inflation also drew people's attention in early 1950s, as shown in the example below:

(52) When the Korean war set off a surge of inflation, few commodity prices shot up faster than those of such critical metals as tin, chromium and copper (TMC 1953/08/17). 
From economists' perspective, inflation is the overall rise of price, and the primary cause of inflation is too much money supply provided by the government or the central bank. During the war period, the government would have to print too much money to support the war. That explains why inflation rose abruptly during the Korean War, Vietnam War, and First Persian Gulf War.

The reason that inflation became rampant in the 1970s and aroused a public concern as suggested in Figure 1 has much to do with the Oil Price Shock and the termination of the Bretton Woods System (1944-1971). The runaway inflation undermines the economy in many ways: it artificially boosts capital gains tax rates because even inflated gains are taxed; it distorts prices and sends out confusing signals to producers and consumers; and it drives up the cost of living faster than wage rates and undermines consumer confidence. The harmful effects caused by galloping inflation let President Ford call it "public enemy number one" and Ronald Reagan describe it as being "as violent as a mugger, as frightening as an armed robber and as deadly as a hit-man" (cf. Mankiw, 2010). This accounts for why the target domain INFLATION has been metaphorically described as A FIRE, AN ENEMY, A RACER, AN ANIMAL, A DISEASE, and all other dangerous things that must be fought against, tamed, outpaced, dampened, and cured.

\section{Conclusion}

The language of economics abounds in metaphors which economics has borrowed from other scientific domains in order to structure itself. The role of metaphor in shaping thought and action is also well documented in the literature (Ortony, 1993; Gibbs, 2008). What is less understood is how metaphors help conceptualize, carry out and sustain large scale intervention in the world, in fields such as politics, the economy and war (Berber Sardinha, 2012: 103). This paper aims to extend this type of inquiry by examining the TIME Magazine Corpus. The results has shown how inflation, an abstract concept and a normal economic phenomenon, is typically understood and explained in a variety of metaphoric expressions, how different types of metaphor structure and reframe our thinking about inflation, and why the usage of inflation metaphor varied over time.

During the researching process, we are increasingly aware that no clear-cut boundaries really exist and some of the metaphors fit into more than one category. Cameron (2007) maintains the impossibility of devising a discrete set of categories into which each metaphor could be reliably placed, and concludes that "there may be nesting of groups within groups. Some metaphors may fit into more than one group, reflecting the indeterminacy of human meaning making". The metaphorical item control, for example, was classified under the heading of mechanic metaphor. Future research can consider recategorize some items into different subtypes of inflation metaphor.

\section{Acknowledgements}

This study is a part of the research projects 1) the Project of Humanity and Social Sciences Key Research Base approved by the Ministry of Education of China (13JJD740005); and 2) the 2012 Project of the Twelfth Five-Year Plan of Guangdong Social Sciences (GD12XWW04) sponsored by Guangdong Social Science Foundation.

\section{References}

Alejo, R. (2010). Where does the money go? An analysis of the container metaphor in economics: The market and the economy. Journal of Pragmatics, 42, 1137-1150. http://dx.doi.org/10.1016/j.pragma.2009.08.013

Berber Sardinha, T. (2012). Metaphors of the Brazilian Economy from 1964 to 2010. In H. Herrera-Soler, \& M. White (Eds.), Metaphor and mills: Figurative language in business and economics (pp. 103-126). Berlin: De Gruyter Mouton. http://dx.doi.org/10.1515/9783110274585.103

Boers, F. (2000). Enhancing metaphoric awareness in specialized reading. English for Specific Purposes, 19(2), 137-147. http://dx.doi.org/10.1016/S0889-4906(98)00017-9

Boyed, R. (1993). Metaphor and theory change: What is a metaphor for? In A. Ortony (Ed.), Metaphor and thought (pp. 481-532). Cambridge: Cambridge University Press. http://dx.doi.org/10.1017/CBO9781139173865.023

Cameron, L. (2007). Patterns of metaphor use in reconciliation talk. Discourse and Society, 18, 197-222. http://dx.doi.org/10.1177/0957926507073376

Charteris-Black, J. (2004). Corpus approaches to critical metaphor analysis. Basingstoke, England: Palgrave Macmillan. http://dx.doi.org/10.1057/9780230000612

Charteris-Black, J. (2000). Metaphor and vocabulary teaching in ESP economics. English for Specific Purposes, 19(2), 149-165. http://dx.doi.org/10.1016/S0889-4906(98)00025-8 
Charteris-Black, J., \& Ennis, T. (2001). A comparative study of metaphor in Spanish and English financial reporting. English for Specific Purposes, 20, 249-266. http://dx.doi.org/10.1016/S0889-4906(00)00009-0

Charteris-Blacka, J., \& Musolff, A. (2003). "Battered hero" or "innocent victim"? A comparative study of metaphors for euro trading in British and German financial reporting. English for Specific Purposes, 22(2), 153-176. http://dx.doi.org/10.1016/S0889-4906(02)00012-1

Crawford Camiciottoli, B. (2007). The language of business studies lectures. John Benjamins B.V. http://dx.doi.org/10.1075/pbns.157

Davies, M. (2007). TIME Magazine Corpus (100 million words, 1920s-2000s). Retrieved October 2015, from http://corpus.byu.edu/time

Gibbs, R. W. (1994). The poetics of mind: Figurative thought, language, and understanding. Cambridge and New York: Cambridge University Press.

Henderson, W. (1982). Metaphor in economics. Economics, 18, 147-153.

Henderson, W. (1994). Metaphor and economics. In R. E. Backhouse (Ed.), New Directions in Economic Methodology (pp. 343-367). London: Routledge. http://dx.doi.org/10.4324/9780203204085.ch16

Henderson, W. (2000). Metaphor, economics and ESP: Some comments. English for Specific Purposes, 19(2), 161-173. http://dx.doi.org/10.1016/S0889-4906(99)00035-6

Henderson, W. (2006). Evaluating Adam Smith: Creating the wealth of nations. London: Routledge.

Henderson, W., \& Dudley-Evans, T. (1990). Introduction: The analysis of economics discourse. In T. Dudley-Evans, \& W. Henderson (Eds.), The language of economics: The analysis of economics discourse (pp. 2-15). London: MEP/British Council. http://dx.doi.org/10.1016/b978-0-408-02680-2.50013-5

Henderson, W., \& Hewings, A. (1990). A language of model building? In T. Dudley-Evans, \& W. Henderson (Eds.), The language of economics: The analysis of economics discourse (pp. 43-54). London: MEP/British Council.

Hu, C. (2014). A Corpus-based analysis of bubble metaphor in economics. Journal of PLA University of Foreign Language, 1, 18-31.

Hu, C., \& Chen, Z. (2015). Inflation metaphor in contemporary American English. Higher Education Studies, 6, 21-35. http://dx.doi.org/10.5539/hes.v5n6p21

Hunston, S. (2002). Corpora in applied linguistics. Cambridge: Cambridge University Press. http://dx.doi.org/10.1017/CBO9781139524773

Jeffreys, D. (1982). Metaphor in economics — an illustrative appendix. Economics, 18(4), 154-157.

Klamer, A., \& McCloskey, D. N. (1992). Accounting as the master metaphor of economics. The European Accounting Review, 1, 145-160. http://dx.doi.org/10.1080/09638189200000008

Koller, V. (2004). Metaphor and gender in business media discourse: A critical cognitive study. Basingstoke, Hants: Palgrave Macmillan. http://dx.doi.org/10.1057/9780230511286

Kövecses, Z. (1991). Happiness: A definitional effort. Metaphor and Symbolic Activity, 6, 29-46. http://dx.doi.org/10.1207/s15327868ms0601_2

Kövecses, Z. (2002). Metaphor: A practical introduction. Oxford: Oxford University Press.

Lakoff, G. (1987). Women, fire, and dangerous things: What categories reveal about the mind. Chicago: The University of Chicago Press. http://dx.doi.org/10.7208/chicago/9780226471013.001.0001

Lakoff, G. (1993). The contemporary theory of metaphor. In A. Ortony (Ed.), Metaphor and thought (2nd ed.) (pp. 202-251). Cambridge: Cambridge University Press. http://dx.doi.org/10.1017/CBO9781139173865.013

Lakoff, G., \& Johnson, M. (1980). Metaphors we live by. Chicago: University of Chicago Press.

Lakoff, G., \& Johnson, M. (1999). Philosophy in the flesh: The embodied mind and its challenge to western thought. New York: Basic Books.

Lakoff, G., \& Turner, M. (1989). More than cool reason: A field guide to poetic metaphor. University of Chicago Press. http://dx.doi.org/10.7208/chicago/9780226470986.001.0001

Mankiw, N. G. (2010). Macroeconomics (7th ed.). Worth Publishers.

McCloskey, D. N. (1985). The rhetoric of economics. Madison: The University of Wisconsin Press. 
McCloskey, D. N. (1990). If you're so smart: The narrative of economic expertise. Chicago: University of Chicago Press.

McCloskey, D. N. (1995). Metaphors economists live by. Social Research, 62(2), 215-227.

Mirowski, P. (1994). Natural images in economical thoughts. Cambridge: Cambridge University Press. http://dx.doi.org/10.1017/CBO9780511572128

Mouton, N. T. O. (2012). Metaphor and economic thought: A historical perspective. In H. Herrera-Soler, \& M. White (Eds.), Metaphor and mills: Figurative language in business and economics (pp. 49-76). Berlin: De Gruyter Mouton. http://dx.doi.org/10.1515/9783110274585.49

O'Mara-Shimek, M., Guillén-Parra, M., \& Ortega-Larrea, A. (2015). Stop the bleeding or weather the storm? crisis solution marketing and the ideological use of metaphor in online financial reporting of the stock market crash of 2008 at the New York Stock Exchange. Discourse \& Communication, 9(1), 103-123. http://dx.doi.org/10.1177/1750481314556047

Radman, Z. (1997). Metaphors: Figures of the mind. Dordrecht/Boston/London: Kluwer Academic Publishers. http://dx.doi.org/10.1007/978-94-017-2254-4

Resche, C. (2012). Towards a better understanding of metaphorical networks in the language of economics: The importance of theory-constitutive metaphors. In H. Herrera-Soler, \& M. White (Eds.), Metaphor and mills: Figurative language in business and economics (pp. 77-102). Berlin: De Gruyter Mouton. http://dx.doi.org/10.1515/9783110274585.77

Samuels, W. J. (Ed.) (1990). Economics as discourse: An analysis of the language of economists. Boston: Kluwer. http://dx.doi.org/10.1007/978-94-017-1377-1

Samuelson, P. A., \& Nordhaus, W. D. (2010). Economics. McGraw-Hill Higher Education.

Semino, E. (2002). A sturdy baby or a derailing train? Metaphorical representations of the euro in British and Italian newspapers. Text, 22(1), 107-139. http://dx.doi.org/10.1515/text.2002.001

Semino, E. (2008). Metaphor in discourse. Cambridge: Cambridge University Press.

Silaski, N., \& Durovic, T. (2010). CATCHING INFLATION BY THE TAIL: Animal metaphoric imagery in the conceptualisation of INFLATION in English. Ibérica, 20, 57-80.

Sinclair, J. (1991). Corpus, concordance, collocation. Oxford University Press.

Smith, G. (1995). How high can a dead cat bounce? Metaphor and the Hong Kong stock market. Hong Kong Papers in Linguistics and Language Teaching, 18, 43-57.

Stefanowitsch, A. (2006). Corpus-based approaches to metaphor and metonymy. In A. Stefanowitsch, \& S. Gries (Eds.), Corpus-based approaches to metaphor and metonymy (pp. 1-16). Berlin: Mouton de Gruyter. http://dx.doi.org/10.1515/9783110199895

Steen, G. J., Aletta, G. D., Berenike, H., Anna, A. K., Tina, K., \& Trijntje, P. (2010). A method for linguistic metaphor identification: From MIP to MIPVU. Amsterdam: Benjamins. http://dx.doi.org/10.1075/celcr.14

White, M. (2003). Metaphor and economics: The case of growth. English for Specific Purposes, 22(2), 131-151. http://dx.doi.org/10.1016/S0889-4906(02)00006-6

\section{Copyrights}

Copyright for this article is retained by the author(s), with first publication rights granted to the journal.

This is an open-access article distributed under the terms and conditions of the Creative Commons Attribution license (http://creativecommons.org/licenses/by/3.0/). 